\title{
Designing Academic Leadership Minor Programs: Emerging Models
}

\author{
Lamine Diallo, Ph.D. \\ Associate Professor Leadership \\ Program Coordinator \\ Wilfrid Laurier University, Ontario \\ Kris Gerhardt, Ph.D. \\ Associate Professor Leadership \\ Wilfrid Laurier University, Ontario
}

\begin{abstract}
With a growing number of leadership programs in universities and colleges in North America, leadership educators and researchers are engaged in a wide ranging dialogue to propose clear processes, content, and designs for providing academic leadership education. This research analyzes the curriculum design of 52 institutions offering a "Minor in Leadership" (13 institutions) or a "Minor in Leadership Studies" (39 institutions) in the United States to evaluate their commonalities and differences using the Brungardt, Greenleaf, Brungardt, and Arensdorf (2006) courses classification model. The results show a large variety of curricular designs with emerging trends. While we recognize the need for flexibility and innovation in program design, in this paper we also argue for greater harmonization of academic leadership program designs.
\end{abstract}

\section{Introduction}

Over the last 30 years, there has been a rapid increase in leadership programs in universities and colleges across North-America (Dugan \& Komives, 2007; Astin \& Astin, 2000). Numerous post-secondary institutions are developing and formalizing the study of leadership at both undergraduate and graduate levels through majors, minors, certificates, or selected course offerings (White, 2006). As society has a growing desire to examine leaders critically in the search for more effective and efficient ways to run organizations, it should be expected that this trend will continue (Stewart, 2006; Middlebrook \& Allen, 2009). But despite the rapid development of academic leadership programs, Jones (2005) points out that "the field of leadership studies has not yet succeeded in articulating a coherent, paradigm-shifting model or approach that both scholars and practitioners can accept and work with" (p. 259). Moreover, despite the growing evidence that structured leadership programs benefit students, little is currently known about the best methods for making such interventions (Posner, 2009). Keating, Rosch, and Burgoon (2014) argue that "very little focus has been directed on specific types of courses that lead to specific types of leadership development" (p. 2).

The rapid development of academic leadership programs has led to a thorough reflection and debate on the nature of leadership studies, and recognition of leadership as a distinct discipline. Environmental scans of academic leadership programs in colleges and universities across North America show a huge diversity of names, designs, and curricular contents 
(Brungardt, Greenleaf, Brungardt and Arensdorf, 2006; Gerhardt \& Diallo, 2013). This variety is explained by the multidisciplinary nature of leadership education (Jenkins \& Dugan, 2013), and the fact that leadership skills and abilities are in demand in almost all fields of study. Differences in the names and designs of these academic programs are informed by the institutional context (Ritch \& Mengel, 2009): the nature of the department housing the program, or of program-based objectives. These differences can create long-term confusion about the identity and scope of the field of leadership as a distinct, unique and important academic discipline.

The objective of this research is two-fold: first, to conduct a review and assessment of the curricular design of programs offering a "Minor in Leadership" or a "Minor in Leadership Studies" in the United States; and secondly, to argue for a minimal standardization of leadership programs curricula. This research seeks to ascertain the underlying academic foundations of leadership minor programs in the United Sates using catalogs, course listings, and program descriptions of similar programs listed on the International Leadership Association (ILA) website in the winter of 2014.

\section{Research in Leadership Minor Programs}

Many universities and colleges in the United States offer a Minor in Leadership. Minor programs are generally offered to provide students with basic training and understanding in a discipline in order to help them combine the learning from their major with another field to build and complement the skills and expertise they acquire through their main program. Due to the reduced number of courses required to fulfill the requirements for an academic minor, it is very important that the minors be designed to cover the specific core expertise and skills the students may need. Consequently, the program designers must focus the selection of courses to those essential to introduce the core skills to be mastered by students. The current research will have implications for the structure of leadership education and development curricula in higher education institutions.

The authors of the current paper were involved in the creation and development of the first undergraduate leadership program in Ontario (Canada). Along with many issues related to carving an academic space for a new multidisciplinary program, there were additional challenges with competing discourses regarding the place and content of leadership education (McLaren, McGowan, Gerhardt, Diallo \& Saeed, 2013). For example, ongoing misconceptions about academic leadership programming by faculty colleagues, recruitment and admissions personnel, current and incoming students, and executive administrators in charge of program funding is one of the challenges encountered in sustaining an Honours BA in Leadership Major program. After 10 years of offering the Honors BA in Leadership, admissions were suspended to focus on the design and delivery of a minor in leadership. This change was intended to allow us to use the available resources to deliver our core leadership courses to a larger proportion of the student body. The most relevant and core courses in the suspended major program were selected to build the academic minor in leadership program. This change created an opportunity to align our course selection with emerging models from other institutions.

The classification model outlined by Brungardt et al. (2006) (see Table 1) provides an excellent instrument to review the commonalities and differences in the curricular designs of 
leadership programs. The model proposes a list of topic areas covered by courses offered by a program and can be useful when analyzing emerging design models of leadership programs. The topic areas include the following six categories: 1. Theories/History; 2. Skills/Behaviors; 3. Context; 4. Issues; 5. Practicum; 6. Support. 
Table 1.

Course Categories and Breakdown as proposed by Brungardt, Greenleaf, Brungardt and Arensdorf (2006)

1. Theories/History

a. Examination of leadership theories and historical foundation

2. Skills/Behaviors

a. Courses that focus on a particular leadership skill or set of skills

b. i.e. Conflict management, strategic planning, decision making

i. General leadership skills

ii. Change making

iii. Communication (including speech)

iv. Critical inquiry

v. Motivation

vi. Conflict management

vii. Decision making

viii. Team processing

ix. Persuasion

x. Planning

xi. Negotiations

xii. Professional skills

xiii. Policy making

3. Context

a. Courses that study leadership in a particular context

b. i.e. Organization, business, community, non-profit

i. Organizational behavior

ii. Leadership

iii. Groups/teams

iv. Society/community

v. International perspectives

vi. Business and social change movements

vii. Politics,

viii. Non-profit

ix. Cultural studies
4. Issues

a. Courses that directly relate to a specific issue

b. i.e. Ethics, gender, law

i. Ethics

ii. Gender issues

iii. Diversity

iv. Law and policy

v. Service and volunteerism

vi. Supervision, public policy

vii. Activism

viii. Human resources

ix. Leadership development and training

5. Practicum

a. Usually independent courses like internships that include hands-on experience in leadership

i. Internship, practicum, senior project

6. Support

a. Usually offered by outside departments that support the leadership curriculum

i. Traditional business

ii. Social research methods

iii. Statistics

iv. Social psychology

v. Public speaking

vi. Psychology

vii. Technology

viii. Public management

7. General Comments

a. Remarks about the degree program as a whole 
The current research will use the coverage of these topic areas to assess the differences and commonalities in the curricular content of programs offering a "Minor in Leadership" or a "Minor in Leadership Studies" in universities and colleges in the United States. We are interested in determining if differences in names are reflected in the curriculum designs of the two types of programs, and how different institutions are covering the topic areas proposed by Brungardt et al. (2006).

\section{Methodology and Results}

Data on leadership programs were collected using the International Leadership Association database (www.ila.org) that provides a listing of self-identified academic leadership programs. This database is searchable and data can be filtered. Although the ILA database does not contain an exhaustive or complete listing of all academic leadership programs, it has sufficient numbers of programs that can be used for comparison purposes.

The ILA database filter used was "classroom based, undergraduate Leadership Minor programs offered in the United States." To maintain consistency and to explore commonalities and differences between "Leadership Minor" or "Leadership Studies Minor" programs, this search was further refined to include only programs labeled with these two designations. The results included 13 programs with a "Leadership Minor" designation and 39 programs with a "Leadership Studies Minor" designation.

In 2009, Bertleson and Goodboy pointed out that departmental websites are commonly used by incoming and current students to gather information. They also suggested that curricular trends could be investigated using data obtained from these types of websites. Following this recommendation, we conducted an environmental scan of the institutional website for each of the 52 programs selected with the purpose of gathering data related to the institutional home of the associated minor, potential association with leadership major programs, as well as required course offerings and their corresponding course descriptions. The investigation of minor degree requirements through a website search should give a representative picture of the overall course content and design of minor programs. Although course descriptions and titles do not contain information regarding evaluations or learning outcomes, they do provide basic information regarding content coverage. Finally, it is important to note that the number of credits required in minor programs vary from institution to institution; most programs are designed by offering a very limited number of leadership courses and by selecting relevant courses from other disciplines to build a minor.

Only required courses were included in the data analysis because these courses should represent the body of knowledge seen as critical to the study of leadership. Conversely, elective courses offered within a minor (or "choose from a list of....") represent areas of subject matter seen as associated, but not critical, to leadership education. Elective courses were not included in the current analysis because there is no guarantee that a student graduating with a Leadership Minor will have taken any of the offered elective courses. Future studies may want to investigate the range of elective offerings available to students taking academic Leadership Minor or Major programs. 
The list of required courses for each program investigated was reviewed by each of the current authors independently. Each of the courses was assigned to one of 5 topic areas discussed by Brungardt et al. (2006): 1. Theories/History; 2. Skills/Behaviors; 3. Context; 4. Issues; 5. Practicum. Originally, Brungardt et al. included a "Support" course category as a sixth topic area, but this category was not used in the current classification as it was deemed to be more applicable to majors and not needed in the current study.

In the instance where a course was found to include topics that could be classified in two or more categories, the authors used a decimal to indicate associated coverage; for example, a course designated 1.2 would indicate a course primarily focused on "Theories/History" with additional coverage or focus on "Skills/Behaviors". In the instance where courses were designated differently by the two authors during independent classification, the course was discussed and reviewed again and a consensus decision was made. "Practicum" courses were never coded in this fashion as the purpose of this type of course is to integrate material from across the curriculum. For the purposes of the following discussion, the primary focus of a course will be considered. Secondary focus or additional noted coverage will be specifically identified as such.

\section{Data Analysis and Research Findings}

Programs affiliation. A survey of the 52 programs (39 Leadership Studies Minor programs and 13 Leadership Minor programs) in the current study reveals a wide variety of academic locations within their respective institutions. In fact, there are 42 unique labels for these academic "homes" including: College of Education and Human Services, School of Business Administration and Entrepreneurship, Department of Agricultural Education and Communication, Department of Psychology, Department of Teaching and Leadership, Department of Political Science, Department of Social Sciences, Department of Educational Leadership, Department of Interdisciplinary Studies, Department of Human Development, and Leadership Institutes or Centers. Of the 52 studied programs, 22 are placed in homes with the word "leadership" in the title. The next most commonly occurring term is "interdisciplinary" with 8 references, followed by "communication" with 5 . The terms "education," "arts and science" and "business" each appear 3 times. These results very clearly indicate that minor programs in leadership education are offered by many different departments/faculty, which suggests the multidisciplinary nature of leadership education and supports previous findings that leadership education is developing in a variety of academic areas (Komives, 2011; Jenkins \& Dugan, 2013; Gerhardt \& Diallo, 2013).

Table 2.

\begin{tabular}{lcccc}
\hline & \multicolumn{2}{c}{$\begin{array}{l}\text { Leadership Minor } \\
\text { programs }\end{array}$} & \multicolumn{2}{c}{$\begin{array}{l}\text { Leadership Studies } \\
\text { Minor programs }\end{array}$} \\
\hline Associated Leadership Major program & Yes & No & Yes & No \\
\hline Quantity & 2 & 11 & 5 & 34 \\
Number of required courses & 5 & 0 to 3 & 1 to 6 & 0 to 7 \\
Average number of required courses & 5 & 2.18 & 4.01 & 2.91
\end{tabular}


A survey of required courses in these 52 programs reveals a wide range of curricular designs (Table 2). Of the 13 Leadership Minor programs in the current study, 2 are from institutions that also have some form of Leadership Major program, although in the case of one institution, the major and minor are housed in different departments/faculties. The results indicate that minor programs from institutions with some form of Leadership Major tend to require more courses than those programs from institutions without a Leadership Major.

Required courses. In terms of overall required courses, in the 13 Leadership Minor programs, there is a total of 34 required courses for an average of 2.61 with a range of 0 to 5 courses depending on the institution. For the 39 Leadership Studies Minor programs, there is a total of 119 required courses for an average of 3.05 with a range of 0 to 7 courses (16 programs offer 2 or 3 courses on the same topic area, for example an institution may required two communication courses, while one program offers 5 courses in one topic area). Two programs (one each identified as "Leadership Minor" and "Leadership Studies Minor") have no required courses, but they include suggestions from a list of courses grouped by theme. At the institution offering a Leadership Minor with no required courses, it is possible to fulfill the requirements for a minor in leadership without ever enrolling in a course with leadership as its primary focus. In fact, it is possible to fulfill the program requirements such that only 1 out of 6 course descriptions includes the word "leadership," and even in this instance it is part of a list of 10 potential topics of discussion.

Out of the 52 programs, the results show a significant difference in required courses from institution to institution. It is apparent from these results that there is no consistency and that even at the post-secondary level, leadership education is viewed and treated differently by different institutions and faculties/departments (Table 3).

Table 3.

\begin{tabular}{lcc}
\hline Topic Areas & $\begin{array}{c}\text { Leadership Minor } \\
\text { programs }\end{array}$ & $\begin{array}{c}\text { Leadership Studies } \\
\text { Minor programs }\end{array}$ \\
\hline Theories/History & 10 & 33 \\
Skills/Behaviors & 8 & 25 \\
Context & 7 & 13 \\
Issues & 3 & 15 \\
Practicum & 6 & 33 \\
Total Programs & 13 & 39
\end{tabular}

Specific courses offered. If we focus on specific courses, we find that there is a wide range of courses offered. A selection of courses offered according to the categories defined by Brungardt et al. (2006) is very diverse. A sample of course titles is listed in Table 4. For example, under the topic area of "Theories/History" we found courses such as Foundations for Leadership, Introduction to Leadership, Theory and Practice, or Exploring Elements of Leadership. 
Table 4.

Sample of course titles

Topic Areas

Sample Course Titles

Theories/History

Foundations for Leadership

Introduction to Leadership: Theory and Practice

Exploring Elements of Leadership

Learning Leadership

Skills/Behaviors

Leadership Values and Virtues

Leadership Strengths and Skills

Communication

Leadership Development

Context

Leadership in a Changing Environment

Principles of Management

Issues

Ethics and Leadership

Ethical Responsibilities of Leadership

Practicum

Leadership Practicum

Applications of Leadership

Internship

We also found that many courses reviewed can be classified under 2 or more topic areas, with "Skills/Behaviors" and "Context" being the most integrated. The courses provided by both Leadership Minor and Leadership Studies Minor are typical of courses we would expect for leadership education programs.

Coverage of topic areas. In order to determine whether there is an observable difference in the number of required courses within each of the 5 investigated topic areas, a twotailed $t$-test (two samples assuming unequal variance) was used. All $t$-tests were run at the 0.05 significance level (Table 5). The analysis indicates that there is little difference in the mean number of courses offered in each topic area between the two types of minor programs. However, there is difference in the coverage of the "Practicum" topic area. While almost $60 \%$ of Leadership Studies Minors include at least one required "Practicum" course, less than $40 \%$ of Leadership Minors include this type of course; which serves as a "wrap-up," or to integrate their previous leadership-related course material. In simpler terms, the difference in the average number of courses required for a Leadership Studies Minor and a Leadership Minor is statistically insignificant, with the exception of the "Practicum" topic area. 
Table 5

\begin{tabular}{lllll}
\hline Topic Areas & $\begin{array}{l}\text { Leadership } \\
\text { Minor }\end{array}$ & \multicolumn{2}{l}{$\begin{array}{l}\text { Leadership } \\
\text { Studies Minor }\end{array}$} & \\
& Mean & Mean & $t$-stat & $p$-value \\
\hline Theories/History & 0.769 & 0.846 & -0.396 & 0.348 \\
Skills/Behavior & 0.615 & 0.641 & -0.107 & 0.457 \\
Context & 0.538 & 0.333 & 1.016 & 0.161 \\
Issues & 0.230 & 0.386 & -0.972 & 0.169 \\
Practicum & 0.461 & 0.846 & -1.736 & 0.048 \\
$N$ & 13 & 39 & &
\end{tabular}

A course with experiential learning as its main focus, such as an internship or a community-based practicum, would provide a measure of practical application that past research has shown to be very valuable for developing leaders. While we find that programs offering a Leadership Studies Minor offer more "Practicum" than programs offering a Leadership Minor, results of the current analysis show that at a majority of institutions a "Practicum" course is required with very few previous requirements. For example, of the 39 institutions offering a Leadership Studies Minor, 13 do not offer a course on "Skills/Behaviors." One might legitimately ask how successful a student will be in applying leadership theories or skills, or leadership within a context before they have been formally exposed to a leadership theory or skills course.

In terms of the number of courses covered in each of the 5 topic areas, it is interesting and potentially important that only 1 program covers all 5 topic areas. This variation indicates that there is little agreement, even at a more general level, on the core areas to cover in a Leadership/Leadership Studies Minor. However, our results also show that both Leadership and Leadership Studies Minors offer more courses in "Theories/History" than in any other topic area (9 of 13 Leadership Minor programs, and 29 of 39 Leadership Studies Minors programs), followed by "Skills/Behaviors." This finding demonstrates the importance that programs place on covering the historical/theoretical and skill foundations of leadership academic education. Because of the limited number of courses provided in minors programs, it should be imperative for programs to cover these two areas.

Research Limitations. It is important to acknowledge that course titles and descriptions give limited information on the course content. Many leadership textbooks today cover similar basic topic areas and introduce students to both leadership theories and skills. As Riggio (2013, p. 11) writes, "the tables of contents of many 'popular' leadership textbooks are remarkably similar." Future research reviewing textbooks used for different courses may be useful in 
determining whether courses offered at different institutions are as similar as they appear in the current analysis. Also, as previously mentioned, some courses did not fit neatly into the classification system proposed by Brungardt et al. (2006), as a result, the sub-classification system described in the methodology was used. The quantitative and macro approach used in this research did not access specific course outlines and syllabi to evaluate the course content. Also, the research only focused on required courses for the reasons identified above.

Several institutions designed programs under institution-specific topic areas, where students are required to select a specific number of courses under each topic area, e.g. "Choose

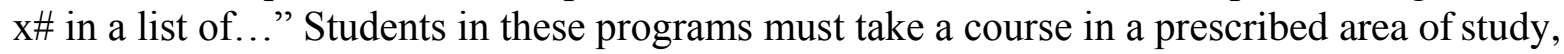
however, since no specific course was required the current analysis did not gather or analyze this information. It is also important to note that our research did not focus on course sequencing, which is an important aspect of program design. A study by Owen and Komives (2007) has suggested that one of the few consistencies of leadership programs is that courses are usually presented in sequential pattern.

General Comments. In summary, all the results detailed above suggest that there is a huge variety of academic programs housing a leadership minor. The results also show that while there are very little differences observed between program designs for Leadership Minor and Leadership Studies Minor programs, except for the "Practicum" courses, there are significant differences observed between the requirements of individual institutions. These results support previous research (Brungardt et al., 2006; Gerhardt \& Diallo, 2013) that the designs of leadership programs show little similarities between institutions. However, the results also suggest that the majority of programs cover the topic areas of "Theories/History" and "Skills/Behaviors." The need to define a core curriculum content, with flexibility to contextualize leadership education, is a necessity if we want to distinguish leadership as a discipline. Riggio (2013) suggests that consensus on a circumscribed knowledge base, research methodology, content and procedures for training, and professional journals and associations are the most important characteristics of a discipline.

Our analysis shows that the differences in program naming are not reflected in the design of programs. With the differences between institutional program designs, it is possible to take a Leadership or Leadership Studies Minor at one institution and never cover the same courses or material as someone taking a leadership minor at a different institution. There is a lack of consistency or, at the very least, agreement on even one core area to cover prior to graduating with a Leadership/Leadership Studies Minor across the 52 programs investigated in the current study. In fact, it is difficult to find more than two institutions that cover the same topic areas in a similar fashion. Efforts toward greater harmonization of curricular content are recognized and debated by many educators and will help to better position leadership academic education.

\section{Context and Arguments for Greater Harmonization of Leadership Academic Programs: A Literature Overview}

Leadership is still a relatively young academic field (Riggio, 2013), which may explain the disparate nature of leadership programs curricular designs. The rapid growth of leadership programs has led to the development of a rich literature that attempts to identify the most suitable 
models for leadership education as a distinct academic discipline. Academic disciplines are organized and clearly demarcated by a set of learning experiences, and are also characterized by specific contents that define their identity. This identity allows students to choose their program based on the expertise they want to acquire, and it also allows employers and parents to identify the competencies acquired by these students upon graduation. When an academic discipline is not clearly defined, it can impact the long-term recognition and positioning of the discipline.

Differentiation and positioning of leadership academic education through program design is essential in fostering a clear and distinct identity. With growing scholarship in leadership theories, competencies and skills, identifying a core curriculum for leadership academic programs has been at the center of many initiatives and research. As summarized by Middlebrooks and Allen (2008), effective leadership education must address foundational questions, such as theoretical framework, curricular content, instructional methods, and assessment. However, as leadership programs continue to increase in number, a lack of consensus still persists regarding what these programs should be designed to teach (Eich, 2008). Riggio (2013) suggests that consensus is the most important characteristic of a discipline and that it is this lack of consensus that is holding back leadership studies from achieving disciplinary status.

Circumscribing the Field of Leadership Study. Leadership educators need to better define the field of study by identifying a minimal and consensual core content for leadership programs, which is more critical with the increased number of stand-alone leadership programs. Recommended curricula could be conceptualized and formulated at a high level of generality, and presented as list of goals, suggested graduation requirements, and general recommendations on content and the sequencing of courses (Glatthorn, Boschee, Whitedhead, \& Boschee, 2016; Komives, Longerbeam, Mainella, Osteen, Owen, \& Wagner, 2009). This curricula also requires the identification of core leadership competencies and the appropriate content standards that programs should cover.

Competencies are areas of knowledge or skill needed by a starting professional in a field (Sanders, 2001). Therefore, each discipline or training program should seek to provide core individual competencies needed by a trainee. Although most academic programs do not have competency models, many have academic accreditation standards that outline the mastery outcomes expected of their graduates (i.e. the Association to Advance Collegiate Schools of Business (AACSB) for Business programs; The Council of Social Work Education (CSWE) for Social Work Programs). In the field of leadership, there is an important body of literature and a common language across academic disciplines on the types of competencies students should have in order to engage in leadership in their respective career fields (Bolden, Gosling, Martunaro \& Dennison, 2003; Seemiller \& Murray, 2013). The challenge for leadership education is that competencies can take different forms in different organizational contexts; in other words, "the underlying purpose of the educators will differ slightly in different venues" (Huber, 2002, p. 29).

Program Positioning. Positioning in academia is an important debate about leadership education. Many theorists assume an important relationship between the study of the liberal arts and the development of leadership skills (Cress, Astin, Zimmerman-Oster \& Burkhardt, 2001). 
Colvin (2003) discusses leadership studies as an integrated discipline in undergraduate liberal education curricula by arguing that one mission for liberal educators is to prepare students for citizenship. Recent research by Sowcik and Allen (2013), and Murphy (2013) also highlights the importance of leadership education for business programs.

With the increasing specialization of disciplines in higher education, Wren, Riggio and Genovese (2009) suggest that the arts, the humanities and sciences are all important areas of study for future leaders with each discipline providing the essential skills, from creativity and communication to rigor in problem solving, needed for leadership. With its interdisciplinary nature, leadership education draws from many other disciplines. But the assessment of existing leadership programs also shows that they differ from these and other fields of study through the combination of courses they provide (Komives et al., 2011).

Curriculum Design Debate. The primary question this research seeks to address is how to use current research findings to further assess and strengthen the identity and differentiation of leadership programs from a curricular perspective. A curriculum design is the heart of the intended learning outcomes of academic disciplines. It provides a carefully ordered sequence of courses based on the intended learning outcomes, including the purpose, content, instructional methods and resources, as well as assessment tools (Lattuca \& Stark, 2009). Identifying learning outcomes associated with leadership programs is a critical component of the design process (Munin \& Dugan, 2011), as student experiences are shaped by how we design program curricula.

The academic discipline of leadership needs to purposefully define a framework for assessing the effectiveness of its curriculum at the levels of knowledge, skills, and attitudes that learners need to achieve through a program. In this regard, studies reported by Watt (2003), Colvin (2003), Bridgeforth (2005), the ILA (2006), Brungardt et al. (2006), Komives et al. (2011) or Gerhardt \& Diallo (2013) are examples of research contributing to a greater understanding and assessment of curricular design models for leadership programs.

The movement toward greater understanding of leadership program curricula has been also recently encouraged through the National Leadership Education Research Agenda(NLERA) (Andenoro, 2013), which suggests a new direction for future leadership education research. Andenoro (2013) reminds us that, "when one attempts to define the merits of a discipline, he or she will normally examine the uniqueness of the body of knowledge represented within that discipline" (p. 2). The NLERA reiterates the importance of defining the content-based priorities with respect to the transfer of learning within the context of leadership education. The report also encourages a "greater understanding of the diversity of the programs in order to provide educators with the potential to design well-crafted curriculum for the development of leadership learners" (p. 9). Rather than being a challenge, the multidisciplinary nature of leadership education provides an opportunity for innovation and "the integration of diverse content and perspectives as well as collaboration across disciplines" (Jenkins \& Dugan, 2013, p. 15).

To encourage the development of a comprehensive program model, the International Leadership Association (ILA) appointed a task force in Summer 2011 a task force to explore questions concerning formalized program review systems, such as a peer review process, accreditation, and/or certification to advance the field of leadership studies (Sowcik, Lindsey, \& 
Rosch, 2013). This process brings with it the need for more conscious attention to the legitimacy and accountability of leadership as a field of study within higher education. Sowcik et al. (2013) highlight the importance of substantive content, skill sets and social behaviors, and standard outlining practices across disciplines as fundamentals to this process. They also recognize the progress of leadership education in these areas but foresee that a formalized program review will create a significant degree of tension within the leadership field. Nonetheless, through the development of a curriculum map/matrix, leadership educators should start to conceptualize how different pieces of leadership program curricula work together by identifying the best content and sequencing of courses.

\section{Conclusion}

Today leadership research and academic programming have reached a critical mass that provides a great potential for in-depth research and program assessment. Assessing program designs, content, and course sequencing is an important step toward identifying emerging models of academic programs. In any discipline, the lack of a clearly articulated curriculum can hinder development and improvement efforts (Schmoker, 2006). As such, professional associations have an important role to play in improving excellence in program design. To facilitate and build a future accreditation system, leadership educators need to continue to assess leadership program designs in order to propose a smaller set of clearer core common contents/standards with some levels of diversity that takes into consideration to the nature of leadership education.

Leadership educators will need to consider the difference between autonomy and anarchy in program design. At the level of curricular design, autonomy allows educators to customize their programs to best serve the interests and needs of current academic climates, current business and employment needs, as well as, the more specific needs of their local community and student population. Even when autonomy is recognized, protected, and encouraged, there must be a measure of consistency. Total autonomy in curricular design, as shown in the current research, with no thought or consideration of existing programs or of existing research does not benefit an academic discipline. In other words, if a new or existing program wants to be identified with a discipline, it is necessary to reference and ensure a base level of consistency with other programs in the same discipline. Autonomy can lead to innovation and wonderful departures from tradition, which serves to strengthen the academic mission of an individual program and eventually a discipline. Unfortunately, autonomy can also trend towards anarchy. Given the vast differences in curricular content and graduation requirements for students with the same designation, the data indicates the lack of an agreed common core, which is indicative of anarchy rather than autonomy.

We do not suggest that complete standardization of leadership minor program curriculum is necessary; in fact we believe the opposite. What we do believe is that without consistency in program names, requirements, or course content, there is a risk of increased confusion inside and outside academic leadership education regarding what "leadership" is from an academic perspective. At the very least, educators designing and teaching in post-secondary leadership education programs must begin, to recognize that the vast differences in curricular design of the current Leadership/Leadership Studies Minors and other studies may be negatively impacting the development of leadership studies as a discipline. 


\section{References}

Andenoro, A. C. (2013). The Inaugural National Leadership Education Research Agenda: A New Direction for the Field. Journal of Leadership Education, 12(1), 1-9.

Astin A. W., \& Astin, H. S. (2000). Leadership Reconsidered: Engaging Higher Education in Social Change. Battle Creek, Mi: WK Kellopp

Bertelson, D. A., \& Goodboy, A. K. (2009). Curriculum Planning Trends: Trends in communication studies, workplace competencies and current programs at 4-year colleges and universities. Communication Education, 58 (2), 262-275. doi: 10:1080/03634520902755458

Bolden, R., Gosling, J., Marturano, A. \& Dennison, P. (2003). A Review of Leadership Theory and Competency Frameworks. Centre For Leadership Studies, Edited Version of a Report for Chase Consulting and the Management Standards Centre, June 2003, University of Exeter.

Bridgeforth, B. W. (2005). Advancing the practice of leadership: A curriculum. Journal of Leadership Education, 4(1), 4-30.

Brungardt, C., Greenleaf, J., Brungardt, C., \& Arensdorf, J. (2006). Majoring in leadership: A review of undergraduate leadership degree programs. Journal of Leadership Education, $5(1), 4-25$.

Cress, C. M., Astin, H., Zimmerman-Oster, K., \& Burkhardt, J. C. (2001). Developmental Outcomes of College Students' Involvement in Leadership Activities. Journal of College Students Development, 42(1), 15-57.

Colvin, R. (2003). Leadership Studies and Liberal Education. Journal of Leadership Education, $2(2), 28-36$.

Dugan, J. P., \& Komives, S. R. (2007). Developing leadership capacity in college students: Findings from a national study. A report from the Multi-Institutional Study of Leadership. College park, Md: National Clearinghouse for Leadership programs.

Eich, D. (2008). A grounded theory of high-quality leadership programs: Perspectives from student leadership development programs in higher education. Leadership \& Organizations Studies, 15(2), 176-187. doi: 10.1177/1548051808324099

Gerhardt, K. \& Diallo, L. (2013). Exploration of Leadership Undergraduate Curricula: A Practical and Critical Review. International Journal of Higher Education and Democracy, 4, (pp. 94-115). State University of New York Press.

Glatthorn, A. A., Boschee, F., Whitehead, B. M., Boschee, B. F. (2016). Curriculum Leadership - Strategies for Development and Implementation. Sage Publications. United States of America.

Huber, N. S. (2002). Approaching Leadership Education In The New Millennium. Journal of Leadership Education 1(1), 25-34. 
Jenkins, D. M., \& Dugan, J. P. (2013). Context Matters: An interdisciplinary Studies Interpretation of the National Leadership Education Research Agenda. Journal of Leadership Education 12(3), Special 2013, 15-29. doi: 10.12806/V12/13/TF1

Jones, A. (2005). Ritual Process, Liminality and Identity in Leadership Development Programs: A Cultural Analysis. Paper presented at the Sixth International Conference on HRD Research and Practice Across Europe, Boulder, CO. Retrieved from http://www.ufhrd.co.uk/wordpress/wp-content/uploads/2008/06/424jones.pdf

Keating, K., Rosch, D., Burgoon, L. (2014). Developmental Readiness for Leadership: The Differential Effects of Leadership Courses on Creating "Ready, Willing, and Able" Leaders. Journal of Leadership Education, Summer 2014. doi: 1012806/V13/13/R1

Komives, S. R. (2011). Advancing Leadership Education. In Komives, S. R., Dugan, J. P., Owen, J. E., Slack, C., Wagner, W., and Associates (Eds.), The Handbookfor Student Leadership Development, National Clearinghouse for Leadership Program $2^{\text {nd }}$ ed. 1-34, Jossey-Bass.

Komives, S. R., Dugan, J. P., Owen, J. E., Slack, C., Wagner, W., and Associates (Eds). 2011. The Handbook for Student Leadership Development, National Clearinghouse for Leadership Program, $2^{\text {nd }}$. Jossey-Bass.

Komives, S. R., Longerbeam, S. D., Mainella, F., Osteen, L., Owen, J. E. O. \& Wagner, W. (2009). Leadership Identity Development: Challenges in Applying a Developmental Model. Journal of Leadership Association, 8(1), 11-47. Retrieved from http://www.journalofleadershiped.org/attachments/article/207/JOLE\%208_1_Komives_ Longerbeam_Mainella_Osteen_Owen_Wagner_2009.pdf

Lattuca, L. \& Stark, J. (2009). Shaping the college curriculum: Academic Plans in Context. San Francisco; Jossey-Bass.

McLaren, P. G., McGowan, R. A., Gerhardt, K., Diallo, L., \& Saeed. A. (2013). Business without the Math: Competing Discourses and the Struggle to Develop an Undergraduate Leadership Program. Journal of Leadership Education 12(2), 1-17.

Middlebrook, A., \& Allen, S. J. (2009). Editors' Introduction: The Education of Leadership. Journal of Leadership Education 8(1), ix-xxiii.

Munin, A., \& Dugan, J. P. (2011). “Inclusive Design”. In Komives, S. R., Dugan, J. P., Owen, J. E., Slack, C., Wagner, W., and Associates (Eds). The Handbook for Student Leadership Development $2^{\text {nd }}$ ed. 157-176. National Clearinghouse for Leadership Program. JosseyBass.

Murphy, S. E. (2013). Commentary on Sowcik and Allen: Getting Down to Business. Journal of Leadership Education 12(3). Special 2013. doi: 10.12806/V12/13/C4

Owen, J.E., \& Komives, S. R. (2007). Does credit matter? Examining the effects of curricular leadership programs. Concepts and Connections, National Clearinghouse for Leadership Programs, 15(3), 1-16.

Palomba, C. A. \& Banta, T. W. (1999). Assessment Essentials: Planning, implementing, and improving assessment in higher education. San Francisco: Jossey-Bass. 
Posner, B. Z. (2009). From Inside Out: Beyond Teaching About Leadership. Journal of Leadership Education 8(1). Summer 2009. Retrieved from http://journalofleadershiped.org/attachments/article/208/JOLE_8_1_Posner.pdf

Riggio, R. E. (2013). Advancing the Discipline of Leadership Studies. Journal of Leadership Education. 12(3), 10-14. doi: 10.12806/V12/13/C2

Ritch, S. W., \& Mengel, T. (2009). Guiding questions: Guidelines for leadership education programs. Journal of Leadership Education. 8(1), 216-227.

Sanders, E. (2001). E-Learning Competencies. Learning Circuits, March 2001.

Schmoker, M. (2006). Results Now: How we can achieve unprecedented improvements in teaching and learning. Alexandria, VA: ASCD.

Seemiller, C., \& Murray, T. (2013). The Common Language of Leadership. In Moreland, J., Burdick, J., Ludorf, M. \& Middlebrooks, A. (Eds). Journal of Leadership Studies, 7(1). 33-45. Retrieved from http://studentleadershipcompetencies.com/wpcontent/uploads/2014/11/346_48481_JLS.pdf

Sowcik, M., Lindsey, J. L., \& Rosch, D. M. (2013). A Collective Effort to Understanding Formalized Program Review. Journal of Leadership Studies, 6(3), 67-72. doi: $10.1002 / \mathrm{j} 1 \mathrm{s.} 21259$

Stewart, J. (2006). Transformational Leadership: An Evolving Concept Examined through the Work of Burns, Bass, Avolio, and Leithwood. Canadian Journal of Educational Administration Policy. Issue 54, CJEAP and the Authors. Retrieved from http://files.eric.ed.gov/fulltext/EJ843441.pdf

The Conference Board of Canada. (2008). New Graduates' Workforce Readiness - The Midmarket Perspective. Research report, The Conference Board Inc.

Watt, W. M. (2003). Effective Leadership Education: Developing a core curriculum for leadership studies. Journal of Leadership Education, 2(1), 13-26. Retrieved from http://www.leadershipeducators.org/Resources/Documents/jole/2003_summer/JOLE_2_ 1.pdf

White, B. J. (2006). Design and Implementation of an Interdisciplinary Leadership Studies Minor at an Historically Black Liberal Arts College. Journal of Leadership Education. 5(2), 50-59.

Wren, J.T., Riggio, R., \& Genovese, M. (2009). Leadership and the Liberal Arts: Achieving the Promise of a Liberal Education. New York, NY: Palgrave Macmillan.

\section{Author Biographies}

Lamine Diallo is an Associate Professor and the Coordinator of the Leadership Program at Wilfrid Laurier University (Brantford Campus, Ontario). He has a PHD. in Sociology and was one of the founding member of the Leadership Program at Laurier in 2003. His research interests 
include Leadership Education and Program Development as well as Leadership and Governance in Africa.

Kris Gerhardt is an Associate Professor in the Leadership and Psychology programs at the Brantford Campus of Wilfrid Laurier University. His research focuses on curriculum design and the prevalence of communication skills courses in postsecondary academic programming. 